\title{
Připravenost $\mathrm{k}$ rodičovství a vztahová vazba
}

\section{Parenthood readiness and attachment}

\begin{abstract}
Abstrakt: Diplomová práce, která je podkladem pro tento příspěvek, se zaměřila na připravenost k rodičovství u mladých dospělých v souvislosti s teorií vztahové vazby a s dalšími faktory (pohlaví, věk, aspekty partnerského vztahu a subjektivní vývojový status). Teoretická část vychází z konceptu teorie vztahové vazby, z poznatků vývojové psychologie a z tematicky relevantních výzkumů. Kvantitativní dotazníkové šetření realizované online se uskutečnilo na vzorku mladých dospělých v České republice ve věku 18-35 let, $\mathrm{N}=659$. Vytvořili jsme dotazník vlastní konstrukce a ke zjištění typu vztahové vazby byla použita Zkrácená česká verze škály Experiences in Close Relationships (ECR-CZ). Pomocí statistického testování jsme došli ke zjištění, že jistý typ vztahové vazby je spojen s vyšší mírou připravenosti k rodičovství. Naopak rozdíl ve vnímané připravenosti k rodičovství mezi muži a ženami nalezen nebyl. Z testování souvislostí dalších faktorů vyplynulo, že připravenost k rodičovství souvisí s věkem, subjektivním vývojovým statusem i s délkou partnerského vztahu, spokojeností ve vztahu a typem soužití partnerů.
\end{abstract}

Klíčová slova: připravenost k rodičovství; vztahová vazba; mladá dospělost

\begin{abstract}
The base for this article is the master thesis that aims at the parenthood readiness of young adults in relation to attachment theory and other factors (gender, age, aspects of relationship and subjective developmental status). The theoretical work is based on the concept of attachment theory, knowledge of developmental psychology and related research. A quantitative online survey was conducted on a sample of young adults in the Czech Republic aged 18-35, $\mathrm{N}=659$. We created a questionnaire of our own construction and a Shortened Czech version of Experiences in Close Relationships (ECR-CZ) was used to identify the attachment style. Using statistical tests, we concluded that a secure attachment style is in connection with a higher degree of parenthood readiness. On the contrary, the difference in perceived parenthood readiness between men and women was not found. Other results of statistical tests, in the context of remaining factors, indicate that parenthood readiness is related to age, subjective developmental status, and length of relationship, relationship satisfaction and the way of cohabitation.
\end{abstract}

Keywords: parenthood readiness; attachment; young adulthood

\section{Koncept vztahové vazby}

V české literatuře je anglický termín attachment překládán různými autory odlišně, a to jako vztahová nebo citová vazba (Brisch, 2011), vztahová vazba nebo citové připoutání (Hašto, 2005), citové pouto (Kubička \& Matějček, 2003), přilnutí (Plháková, 2007) nebo teorie přimknutí (Fonagy \& Target, 2005). Pro označení celé teorie (attachment theory) v české literatuře (u výše uvedených autorů) spojení jako teorie attachmentu, teorie přilnutí, teorie připoutání, teorie (rané) vztahové vazby nebo teorie citové vazby. Pro účel tohoto príspěvku budeme používat termíny vztahová vazba a teorie vztahové vazby.

Jedná se o pohled z evoluční perspektivy, kdy poskytnutí ochrany a obnovení pocitu bezpečí plní biologickou funkci, potřebu přežití (Bowlby, 1988). Vztahovou vazbou potom rozumíme citové pouto a unikátní přilnutí mezi dítětem a jeho pečovatelskou osobou/osobami (nejčastěji rodič/e), které mu v útlém věku poskytují pocit bezpečí. Jedná se o unikátní vztah vybudovaný na základě bazální důvěry či nedủvěry mezi těmito jedinci, který je podmínkou a nedílnou součástí budování pozdějších blízkých a komplexních vztahů (např. v dospělosti) (Brisch, 2011; Hartl, Císařová, \& Nepraš, 2010).

Počátky teorie vztahové vazby se pojí se jménem Johna Bowlbyho (1907-1990), anglického psychologa, který ve svém výzkumu snoubil pozorování ze své praxe při práci s dětmi, poznatky z evoluční biologie a psychoanalytické úvahy (Bowlby, 2010). S počátky vzniku teorie vztahové vazby je spojeno i jméno Mary Ainsworthové (1913-1999), americké psycholožky. Ta při svém doktorském studiu prakticky ověřovala teorii bezpečí (theory of security), kterou postuloval její vedoucí William Blatz a ve které byl poprvé použit termín bezpečná základna (secure base), dnes tak zásadní pro teorii vztahové vazby (Goldberg, 2000). Klíčovou byla její první empirická studie realizovaná v Ugandě, kde byla zkoumána interakce mezi matkou a dítětem. Výsledky této studie přispěly ke vzniku metody „neznámá situace“ (strange situation)1, na základě které jsou

\footnotetext{
${ }^{1}$ Neznámá situace je metoda, ve které se pozorují reakce dítěte na krátké odloučení od vazebné osoby, reakce na př́chod cizince
} 
kategorizovány typy vztahové vazby (Ainsworth, Bell, \& Stayton, 1971).

\subsection{Vazebný systém a vazebné chování}

Jak již bylo zmíněno výše, vztahy, které jsou utvářeny mezi dětmi a jejich pečujícími osobami, jsou založeny na biologickém podkladu, kterému můžeme nejlépe porozumět v kontextu evoluce. Nejedná se jenom o okamžiky bezprostředně po narození potomka. Dítě je na svých rodičích závislé nejen několik prvních měsíců, ale i let. Toto období je charakteristické vyhledáváním blízkosti a poskytováním péče, základními projevy vazebného systému (attachment system) (Howe, 2011).

Neopominutelnou součástí vazebného systému je vazebná osoba (attachment figure), která by měla sloužit jako tzv. bezpečný prrístav (safe haven), kde dítě v případě potřeby, pocitu ohrožení či strachu najde komfort, ochranu a bezpečí. Pokud je vazebná osoba v takovýchto př́padech dostupná, citlivá a vnímavá $\mathrm{k}$ potřebám dítěte, plní také druhou nezbytnou funkci, a to funkci bezpečné základny (secure base). Díky ní se dítě může pustit do explorace okolí a s vědomím dostupnosti vazebné postavy vnímá prostředí jako bezpečné (Bowlby, 1988). Pečující osoby, které poskytují dítěti bezpečnou základnu, mu umožňují být samostatné, zvídavé a experimentovat (Howe, 2011) a pomáhají mu udržovat emoční rovnováhu a budovat odolnost vůči stresu (Obegi \& Berant, 2009).

Jedním z klíčových tvrzení teorie vztahové vazby je, že zkušenosti z předešlých vztahů ovlivňují, jak se budou lidé chovat ve vztazích následujících (Howe, 2011). Na základě těchto zkušeností si jedinec formuje mentální reprezentace o tom, jak svět fungoval v minulosti, a jak by mohl fungovat $\mathrm{v}$ budoucnosti. Tyto mentální reprezentace jsou v kontextu teorie vztahové vazby klíčové a označujeme je pojmem vnitřní pracovní modely (internal working models) (Hazan \& Shaver, 1994; Howe, 2011). Bowlby (2010) postuluje, že si jedinec utváři dvě kategorie těchto modelů: 1) sebe sama (the self) a 2) druhých (other people), jinak řečeno modely světa a sebe v něm. Vnitřní pracovní modely obsahují očekávání (expectations) a přesvědčení (beliefs) 1) o chování sebe sama a ostatních, 2) o vlastní hodnotě a přijetí sebe sama a 3) o emoční dostupnosti a zájmu ostatních, stejně jako o jejich schopnosti poskytnout jedinci ochranu (Bowlby, 2010; Howe, 2011).

\subsection{Typy vztahové vazby}

Mary Ainsworthová a její metoda „neznámá situace“ jsou, jak již bylo zmíněno výše, spojeny s první typologií typů vztahové vazby u dětí (Ainsworth, Bell, \& Stayton, 1971). Výsledky klinického pozorování a následné

a poté na návrat vazebné osoby. Dle projevů chování dítěte se určuje typ vztahové vazby. statistické analýzy vedly k pojmenování základních tř́i kategorií: B - jistá (secure), A - nejistá-vyhýbavá (avoidant) a C - nejistá-úzkostná (ambivalentní) (ambivalent) (Bowlby, 2010; Goldberg, 2000). Čtvrtý typ byl pojmenován později na základě podrobnějšího zkoumání obtížně klasifikovatelného chování některých dětí $\mathrm{v}$ testové situaci. Analýzou tohoto chování, které nebylo možné popsat ani jedním z existujících typů $(A, B, C)$, dospěla Mary Mainová a Judith Salomonová (1990; in Goldberg, 2000) k nutnosti dodat čtvrtý typ, a to typ D - nejistá dezorganizovaná (desorganized). Pojmenování jednotlivých typů u dospělých jedinců se liší, např. Šolcová (2009) používá pouze rozlišení dvou základních typů vazby - jistá a nejistá (úzkostná), Obegi a Berant (2009) hovoří o typu vztahové vazby jisté (secure), zaujaté (preoccupied), distancované (dismissing) a bázlivé (fearful), zatímco Brisch (2011) používá prakticky stejné dělení na čtyři skupiny jako Mainová a Salomonová (1990; in Goldberg, 2000). I přes různá pojmenování zůstává charakteristika jednotlivých typů stále stejná.

V návazných výzkumech se Brennan, Clark a Shaver (1998) shodují, že pro nazírání na koncept vztahové vazby je vhodnější dvoudimenzionální typologie, která znázorní rozdíly v interpersonálních vztazích. Jedná se o dvě ortogonální dimenze: 1) vztahovou úzkostnost (obavy z odmítnutí, separace, opuštění) a 2) vztahovou vyhýbavost (nepohoda v situacích směřujících k závislosti na druhém a vyhýbání se intimitě).

Stručně můžeme jednotlivé typy vztahové vazby charakterizovat takto:

- Bezpečný (jistý) typ vazby - charakterizovaný nízkým stupněm vyhýbavosti i úzkostnosti. Vnitřní pracovní model sebe i ostatních je pozitivní. Dospělí jedinci s jistým typem vazby se cítí př́ijemně sami se sebou (cení si své autonomie), stejně jako v situacích blízkosti a intimity s druhými. Vztah dvou lidí s jistým typem vazby je potom charakteristický vzájemnými projevy péče, ujištování a podpory, což vede ke spokojenosti obou jedinců (Howe, 2011).

- Úzkostný/ambivalentní (zaujatý) typ vazby - je spojován s vysokým stupněm úzkostnosti, ale nízkým stupněm vyhýbavosti. Vnitřní pracovní model sebe je negativní, zatímco ostatní jsou vnímáni pozitivně a jedinec jim touží být nablízku. Výsledkem je přehnaná emoční závislost na druhých lidech. Pokud je někdo odmítne, přikládají vinu sami sobě, čímž ponižují vlastní self a udržují pozitivní obraz o ostatních (Brennan et al., 1998; Howe, 2011). Tito jedinci jsou pohlceni svými pocity. Emoce v oblasti partnerských vztahů vyjadřují přehnaně. Snadno a rychle se zamilují, ale jejich vztahy se často rozpadají, když začnou být př́liš důvěrné. Charakteristická je pro ně i výrazná žárlivost (Mikulincer \& Shaver, 2007).

- (Distancovaně) vyhýbavý typ - vyznačuje se vysokým stupněm vyhýbavosti a nízkým stupněm 
úzkostnosti. Vnitřní pracovní model sebe je pozitivní a model ostatních negativní (Brennan et al., 1998; Howe, 2011). Navzdory tomu, že se necítí hodni lásky, vnímají sami sebe jako nezávislé a silné. Samostatnost, stejně jako vyhýbání se fyzickému i emočnímu kontaktu, je pro ně př́ijemnější než blízkost s druhým člověkem. (Distancovaně) vyhýbaví jedinci pocitují nepohodu v intimním vztahu, potlačují své vztahové potřeby a vyhýbají se závislému postavení. Vyhýbavost je pro ně strategií, jak si udržet pocit bezpečí, což ve spojení se strachem $\mathrm{z}$ intimity vede $\mathrm{k}$ častému rozpadu jejich vztahů (Hazan \& Shaver, 1987).

- Dezorganizovaný (bázlivě vyhýbavý) typ vazby typické jsou vysoké skóry v obou dimenzích, tedy úzkostnosti i vyhýbavosti. Vnitřní pracovní model sebe i ostatních je negativní (Brennan et al., 1998; Howe, 2011). Tyto osoby mají nízké sebevědomí, jsou vysoce labilní, introvertní a stejně jako předchozí typ vykazují vysokou míru osobního distresu a nedůvěry vůči ostatním. Vztahy s druhými jsou plné chaosu, dezorganizované a nepředvídatelné. I přes to, že se $\mathrm{v}$ př́ítomnosti vztahové osoby trápí, často ji nedokážou opustit (Hazan \& Shaver, 1987). $\mathrm{V}$ důsledku toho, že nejsou schopni zpracovávat svoje emoce ani rozpoznat emoce druhých, pocitují frustraci, která může ve vztahu vyústit až do agrese (Howe, 2011).

\section{Dosažení dospělosti, partnerství a rodičovství}

Jednoznačná definice dospělosti v psychologii není, stejně jako mezi odborníky chybí shoda $\mathrm{v}$ tom, kdy dospělost začíná. $V$ terminologii nového občanského zákoníku České republiky se dle $\$ 30$ „plně svéprávným člověk stává zletilostí. Zletilost se nabývá dovršením osmnáctého roku věku“ (\$ 30 zákona č. 89/2012 Sb., občanský zákoník, ve znění pozdějších předpisů). Zletilý jedinec potom může např. uzavrít závaznou smlouvu, jít do zaměstnání, vstoupit do manželství, volit ve volbách, pít alkohol, řídit auto, vstoupit na stránky s erotickým obsahem. Je ale takový člověk opravdu s úderem 18. narozenin vyzrálý a dospělý?

Z pohledu vývojové psychologie je jedním z kritérií dospělosti dosažení osobní zralosti. Thorová (2015) a Langmeier a Krejčířová (2006) uvádějí následující charakteristiky zralosti:

- samostatnost fungování, nezávislost (na rodičích), ekonomická soběstačnost;

- efektivní pracovní a společenské uplatnění;

- získávání odpovědnosti v profesi;

- zralé fungování v mezilidských vztazích (formálních, partnerských);

- schopnost adaptace na nové životní situace, odolnost vi̊či zátěži, kontrola emocí;

- upřesnění osobních cílů;
- schopnost reálného plánování budoucnosti;

- zakládání vlastní rodiny.

Vedle výše uvedeného je možné jmenovat ještě překonání rozporu dětství a dospívání, kdy si dospělý člověk má s rodiči udržet kladný vztah, a přesto na nich být nezávislý, vytvořit si nové pouto $\mathrm{k}$ partnerovi a zároveň zachovávat prátelské vztahy, prrípadně navazovat nové (Říčan, 2004). Jak uvádějí Langmeier a Krejčířová (2006, 107), je zřejmé, že „rưzní lidé dosahují rưzné míry zralosti v různém čase a různým tempem“. Moderní společnost se navíc vyvijí a nabízí dospívajícím další možnosti uplatnění. V dnešní době je mladým lidem umožněno cestovat, studovat $\mathrm{v}$ zahraničí a sbírat zkušenosti, které jsou na pracovním trhu ceněny (Thorová, 2015). Lidé dosahují osobní zralosti ve vyšším věku, manželství se uzavírají později, věk prvorodiček je vyšší. Dle Demografické př́ručky 2016 Českého statistického úřadu (ČSÚ, 2017a) shrnující údaje v období let 1950-2016 byl průměrný věk svobodného ženicha v roce 2016 32,1 let (o 5 let více než v roce 2000). Průměrný věk svobodné nevěsty $\mathrm{v}$ roce 2016 byl 29,5 let (4,9 let více než v roce 2000). Dále lze pozorovat také odkládání založení rodiny. Pro větší přehlednost další údaje shrnujeme v následujícím grafu (obr. 1), který poukazuje především na zvýšení počtu prvorodiček ve věku 30-34 let a snížení jejich počtu ve věkové kategorii 20-24 let (Český statistický úrad, 2017a).

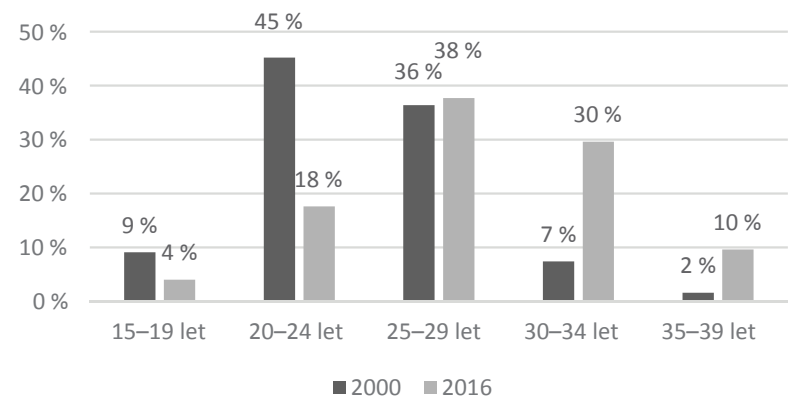

Obr. 1: Prvorozené děti dle věku rodičky (ČSÚ, 2017a)

I vzhledem $\mathrm{k}$ těmto společenským posunům přišel J. J. Arnett $(2000,2004)$ s konceptem vývojové fáze vynořujicí se dospělosti (mezi 18-25 lety), která je charakteristická hledáním identity, orientací na vlastní osobu, obecnou nestabilitou (změny bydliště, školy, popř. hledání zaměstnání a navazování nových vztahů) a zkoušením různých možností, kdy se jedinci cítí „někde mezi“ dospíváním a plnou dospělostí. Vymezil se tak proti původní definici mladé dospélosti coby období stabilizace životních postojů a naleznutí stabilního partnera a zaměstnání, jak ji pojímá např. Erikson (1968) mezi 20.-40. rokem, Ř́ćan (2004) mezi 20.-30. rokem, Švancara (1981) v rozmezí 20-32 let a Thorová (2015) ve věku 20-35 let. Jiní autoři používají termín raná dospělost, např. Levinson $(1996,1978)$ jím označuje 
22.-40. rok a přidává přechodnou fázi rané dospělosti (17-22 let) a Hurlocková (1980) jím označuje období věku 21-40 let. Popř́padě v literatuře najdeme označení časná dospělost, kterou Langmeier a Krejčířová (2006) vymezují 20.-25./30. rokem života. S ohledem na překryvy v definicích jednotlivých autorů budeme dále v této práci používat označení „mladá dospělost“ pro období 18-35 let.

Podle starší literatury (např. Hurlocková, 1980; Vágnerová, 2007) patři mezi vývojové úkoly mladé dospělosti vedle rozvíjení intimity $\mathrm{v}$ rámci partnerských vztahů také založení rodiny. Stát se rodičem, to je událost popisovaná jako zdroj velké radosti, ale i velké změny. Období mladé dospělosti s sebou nese (především pro mladé ženy) také tíhu dilematu o rozhodování mezi kariérou na plný úvazek a rodičovstvím. Jedná se svým způsobem o stresující událost, u které mladí dospělí kladou větší důraz na plánování a přemýšlejí o následných dopadech tohoto rozhodnutí do budoucnosti. Často si také uvědomují, že se jedná o ztrátu svobody a úbytek intimity ve vztahu (O'Laughlin \& Anderson, 2001). Také můžeme mluvit o přijímání odpovědnosti za své činy jako o znaku osobní zralosti a o přípravě na přijetí odpovědnosti za druhého člověka - budoucího potomka. I vzhledem $\mathrm{k}$ výše uvedeným statistikám se tento mezník, zplození dítěte, někdy oddaluje až do dospělosti střední. Mladí dospělí ale děti a priori neodmítají. Poukazují na to např. výsledky výzkumu Petry Diviśkové (2017), kde respondenti ve věku 18-25 let $(\mathrm{N}=1428)$ v $83 \%$ po dětech touží, necelá $2 \%$ je již mají a pouhých téměř $10 \%$ neví, jestli je chce. Lze se ovšem ptát, které faktory přispívají $\mathrm{k}$ tomu, zda se člověk $\mathrm{v}$ tomto věku cítí či necítí být pripraven převzít roli rodiče. Mezi ty nejčastěji jmenované, které jsou současně předmětem našeho výzkumu, patří pohlaví, věk, vzdělání, partnerský vztah (délka, spokojenost, soužití) a subjektivní vývojový status.

\section{Subjektivní vývojový status, vztahová vazba a další mediátory připravenosti k rodičovství}

Období mladé dospělosti, jak jej pojímáme v této práci (18-35 let), je rozprostřeno do 17 let. Je tak přirozené, že 18letí, kteří stojí na prahu mladé dospělosti, k rodičovství přistupují odlišně ve srovnání s jedinci kolem 30. roku věku.

Jedním z důležitých faktorů je partnerský vztah, a to nejen jeho existence, ale i délka tohoto vztahu a spokojenost v něm (Fialová et al., 2000; Kamp Dush et al., 2014). Dále uvádíme roli pohlaví, kdy se ženy cítí být připraveny dř́ve než muži na základě pocitu, že je jim role matky dána (Spiteri et al., 2014). Popisujeme také věk a především subjektivní vývojový status, jenž věk jako jeden $\mathrm{z}$ faktorů ovlivňuje. Jedinci, kteří se cítí být „někde mezi“ $v$ terminologii vynořující se dospělosti, se na rodičovství cítí méně připraveni než ti, kteří se identifikují jako dospělí (Macek et al., 2007). Posledním uváděným možným mediátorem je vztahová vazba v kontextu partnerského vztahu, která anticipuje očekávání vztahové vazby rodič-dítě. Jedinci s nejistým typem vazby očekávají více negativní vztahy mezi nimi jako rodičem a jejich dítětem (např. nejistotu ve schopnosti k dítěti přilnout) (Rholes et al., 1997).

\section{Výzkum}

Hlavním cílem našeho výzkumu bylo zjistit, zda existuje souvislost mezi typem vztahové vazby (jistý-nejistý) a připraveností $\mathrm{k}$ rodičovství u mladých dospělých (18-35 let) v České republice. Sekundárním cílem bylo ověření souvislosti dalších faktorů s připraveností k rodičovství - pohlaví, věku, aspektů partnerského vztahu (délky, spokojenosti, typu soužití) a subjektivního vývojového statutu - které byly vybrány na základě rešerše pro teoretickou část práce. $\mathrm{V}$ souladu s výše uvedenými cíli byly stanoveny následující hypotézy:

H1: Jistý typ vztahové vazby je spojen s vyšší mírou připravenosti k rodičovství než nejistý typ vztahové vazby. H2: Existuje rozdíl mezi muži a ženami ve vnímané připravenosti k rodičovství.

H3: Existuje souvislost mezi věkem respondenta a vnímanou prripraveností $\mathrm{k}$ rodičovství.

H4: Existuje souvislost mezi délkou současného partnerského vztahu a vnímanou připraveností k rodičovství.

H5: Existuje souvislost mezi spokojeností v partnerském vztahu a vnímanou připraveností k rodičovství.

H6: Existuje rozdíl mezi lidmi v různém typu partnerského soužití ve vnímané připravenosti k rodičovství.

H7: Existuje souvislost mezi subjektivním vývojovým statusem a vnímanou pripraveností k rodičovství.

\subsection{Popis metodologického rámce a metod}

Pro naplnění cíle výzkumu a ověrení stanovených hypotéz byl zvolen primárně kvantitativní design. Konkrétně se jednalo o kvantitativní dotazníkové šetření realizované online. Dotazník pro respondenty se skládal celkem ze tří částí.

V první ćásti respondent vyplňoval základní údaje o sobě (věk, pohlaví, vzdělání, rodinný stav, délku vztahu a další informace o partnerském vztahu atd.). Druhá část byla zaměřena na typ vztahové vazby zjištované dotazníkem ECR-CZ (popis metody níže v kapitole 4.1.1.). V části poslední jsme se dotazovali na „závazek a exploraci rodičovství, kde bylo kvantitativní dotazníkové šetření inspirované škálou GIDS v úvodu doplněno o jednu kvalitativní otázku („Nyní na chvíli zpomalte, zamyslete se a predstavte si sebe $v$ roli rodiče. Zkuste svou představu krátce popsat, co zahrnuje, jak se citíte. Pokud zatím žádné predstavy nemáte, je to $v$ pořádku, napište nám i to."), na kterou dotazník navazoval. 
Samotnému ostrému dotazníkovému šetření předcházelo pilotní testování. Na základě sesbíraných podnětů a připomínek došlo především ke stylistickým úpravám u tvrzení týkajících se připravenosti k rodičovství. Dále jsme přidali kvalitativní otázku na úvod třetí části, jejímž účelem bylo smysluplně převést respondenta do oblasti představy o vlastním rodičovství, na kterou se dotazujeme v otázkách následujících. V neposlední řadě pilotní testování vedlo ke změně webové platformy pro realizaci výzkumu. Pro sběr dat byla zvolena online platforma společnosti Click4Survey, která umožnila obsahové i grafické úpravy dle našich potřeb.

Vyhodnocení hypotéz probíhalo za použití deskriptivní a inferenční statistiky, vzhledem k normálnímu rozložení proměnných (Shapiro-Wilkův test, $\mathrm{p}>0,05$ ) konkrétně prostřednictvím t-testu, jednofaktorové analýzy rozptylu (ANOVA) s následným Tukeyho post-hoc testem a za pomoci Pearsonova korelačního koeficientu. Výjimkou byla hypotéza $\mathrm{H} 7, \mathrm{kdy}$ rozložení proměnné „subjektivní vývojový status“ napovídalo spíše použití Spearmanova korelačního koeficientu. Pro upřesnění míry účinku bylo také vypočítáno Cohenovo d.

\subsubsection{ECR-CZ (Zkrácená česká verze škály Experiences in Close Relationships)}

Druhá část dotazníku byla tvořena položkami škály ECR-CZ. Původními autory škály Experinces in Close Relationships (ECR) jsou Brennanová, Clarková a Shaver (1998). Výběrový soubor pro vznik této škály čítal 1086 respondentů (univerzitní studenti), kteří odpovídali na 323 položek. Při vývoji bylo na počátku stanoveno 60 subškál, z nichž po testování vzešly dva dominantní faktory. Ty odpovídají dvěma škálám, které mají odpovídající reliabilitu i validitu: 1) škála vztahové úzkostnosti a 2) škála vztahové vyhýbavosti, které dohromady obsahují 36 položek. Jedná se o položky Likertova typu a jsou hodnoceny na sedmibodové stupnici od 1 - rozhodně nesouhlasím po 7 - rozhodně souhlasím. Některé položky mají reverzní znění (Brennan et al., 1998). Od roku 1998, kdy byla škála publikována, ji výzkumníci použili v desítkách studií, jejichž souhrn uvádí např. Mikulincer a Shaver ve své publikaci z roku 2007. Škála se vyskytuje také v různých modifikacích, např. ECR-R (Fraley, Waller, \& Brennan, 2000) nebo námi využitá ECR-CZ (Seitl et al., 2016). O překlad ECR do českého jazyka a pilotní studii na vzorku českých a amerických studentů se zasloužili Lečbych a Pospíšilíková (2012). České normy vytvořili Seitl, Charvát a Lečbych (2016). Právě zmíněná trojice autorů navrhla při tvorbě norem verzi ECR-CZ.

Zkrácená česká verze Experiences in Close Relationships, neboli ECR-CZ, obsahuje 31 položek rozdělených do dvou na sobě nezávislých škál, přičemž položky jsou hodnoceny na sedmibodové stupnici Likertova typu. Výsledkem každé škály je T-skór (doporučený cut off score střed + $1 \mathrm{SD}$ ), který pro interpretační účely slouží ke kategorizaci (viz tab. 1) (Seitl et al., 2016).

Tab. 1: Interpretace T-skóru

\begin{tabular}{lc}
\hline Hodnota T-skóru & Typ vztahové vazby \\
\hline T-skór $<60$ & jistý \\
T-skór na škále úzkostnosti $>60$ & úzkostný \\
T-skór na škále vyhýbavosti $>61$ & vyhýbavý \\
T-skór na škále úzkostnosti i vyhýbavosti zároveň $>61$ & dezorganizovaný \\
\hline
\end{tabular}

\subsection{Výzkumný soubor}

Pro výběr výzkumného souboru byl použit nepravděpodobnostní výběr, konkrétně metody přiležitostného výběru a sněhové koule. Dotazník byl administrován prostřednictvím webového odkazu umístěného na sociální síti a sdíleného e-mailem. Odkaz na dotazník byl otevřen celkem 2892krát, $\mathrm{z}$ toho 670 respondentů průzkum dokončilo (23\%) a 267 v průběhu od vyplňování upustilo ( $9 \%$ ze všech započatých administrací). Po očištění a kontrole dat výsledný výzkumný soubor čítal 659 respondentů ve věku 18-35 let. Podrobné analýze byla podrobena skupina „nerodičư “ $(\mathrm{N}=620)$, kteří byli primární cílovou skupinou této výzkumné práce.

Tab. 2: Deskriptivní charakteristiky dle rodičovského statusu

\begin{tabular}{lcc}
\hline Nerodiče & Počet & \% ze základního souboru \\
\hline Muži & 110 & $16,7 \%$ \\
Ženy & 510 & $77,4 \%$ \\
Celkem & 620 & $94,1 \%$ \\
\hline
\end{tabular}

\section{Výsledky}

Průměrný věk respondentů činil 23,60 let $(S D=3,11)$, přičemž ženy byly průměrně o rok mladší $(M=23,43$; $\mathrm{SD}=2,94)$ než muži $(\mathrm{M}=24,36 ; \mathrm{SD}=3,71)$. Více než polovina respondentů, konkrétně $72 \%(\mathrm{~N}=443)$, byla v době vyplňování v partnerském vztahu a zbylých $28 \%$ jedinců $(\mathrm{N}=173)$ bylo nezadaných. Typ soužití respondentů ve vztahu uvádíme podrobně v tabulce 3 . Nejčastěji zastoupeno bylo společné soužití, kdy tuto odpověd' označilo 186 respondentů (42\%), následováno bylo společným vídáním se v průběhu celého týdne. Tak funguje vztah 132 respondentů (30\%). Níže uvádíme popisné statistiky dle typu soužití společně s hodnotami průměrů a směrodatných odchylek (SD) proměnných přpravenost $k$ rodičovství a spokojenost ve vztahu. 
Tab. 3: Popisné statistiky dle typu soužití - „Nerodiče ve vztahu $(\mathrm{N}=443)^{\text {“ }}$

\begin{tabular}{lccccc}
\hline Typ partnerského soužití & Počet (N) & $\begin{array}{c}\text { Průměr } \\
\text { „připravenost" }\end{array}$ & SD „připravenost“ & $\begin{array}{c}\text { Průměr } \\
\text { "spokojenost“ }\end{array}$ & $\begin{array}{c}\text { SD } \\
\text { "spokojenost“ }\end{array}$ \\
\hline bydlíme s př́telem/př́telkyní spolu & 186 & 4,42 & 1,41 & 5,80 & 1,05 \\
manželství & 47 & 5,72 & 1,58 & 6,30 & 0,78 \\
vídáme se přes týden (po-ne), ale nebydlíme spolu & 132 & 3,92 & 1,07 & 5,75 & 1,09 \\
vídáme se jen o víkendech (prázdninách, svátć́ch) & 70 & 4,03 & 1,26 & 5,76 & 1,01 \\
vztah na dálku (vídáme se méně než 1× za měsíc) & 8 & 4,25 & 0,71 & 5,88 & 0,83 \\
\hline Všechny skupiny & 443 & 4,35 & 1,40 & 5,83 & 1,04 \\
\hline
\end{tabular}

Proměnná „subjektivní vývojový status“ má průměr $5,22(\min .=1, \max .=7 ; \mathrm{SD}=1,09)$, čímž nám říká, že většina nerodičů se přiklání více $\mathrm{k}$ pólu dospělosti než nedospělosti. Jistý typ vztahové vazby se vyznačoval hodnotou T-skóru nižší než 60 a byl zastoupen 465 respondenty (75\%). Nejistý typ byl dán hodnotou vyšší než 61 na škále úzkostnosti nebo vyhýbavosti, což v našem vzorku splňovalo 155 respondentů (25\%). Pokud bychom hovořili o 4 kategoriích typu vztahové vazby, je procentuální zastoupení shrnuto v následujícím grafu (obr. 2).

Obr. 2: Typy vztahové vazby

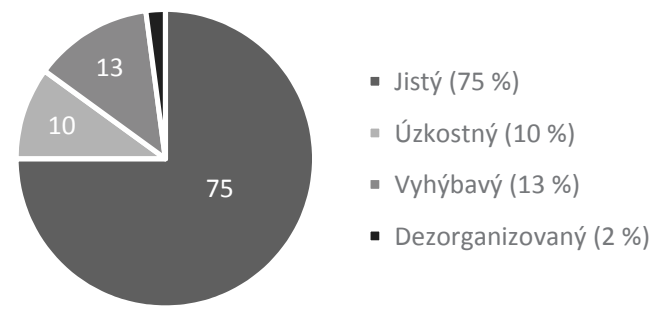

Po otestování jednotlivých hypotéz byly výsledky následující:

- Vnímaná připravenost lidí s jistým typem vztahové vazby $(\mathrm{N}=465)$ je vyšší než vnímaná připravenost lidí s nejistým typem vazby $(\mathrm{N}=155)(\mathrm{t}=-3,187$; $\mathrm{p}=0,001)$. Vypočtená míra účinku vyjádřená Cohenovým $\mathrm{d}=0,32$, což značí pouze malou praktickou významnost.

- Zjištěné hodnoty nesvědčí pro rozdíl ve vnímané připravenosti k rodičovství mezi muži $(\mathrm{N}=110)$ a ženami $(\mathrm{N}=510)(\mathrm{t}=1,78 ; \mathrm{p}=0,75)$.

- Věk respondenta slabě pozitivně souvisí s vnímanou připraveností $\mathrm{k}$ rodičovství $(\mathrm{r}=0,22 ; \mathrm{p}<0,001)$.

- Délka partnerského vztahu slabě pozitivně souvisí $s$ vnímanou připraveností $\mathrm{k}$ rodičovství $(\mathrm{r}=0,25$; $\mathrm{p}<0,001)$.

- Spokojenost v partnerském vztahu taktéž slabě pozitivně souvisí $s$ vnímanou připraveností k rodičovství ( $\mathrm{r}=0,19 ; \mathrm{p}<0,001)$.

- Zjištěné hodnoty svědčí pro rozdíl mezi lidmi $\mathrm{v}$ různém typu soužití $\mathrm{z}$ hlediska jejich připravenosti k rodičovství. Nejsilnější vztah k připravenosti $\mathrm{k}$ rodičovství byl prokázán u respondentů, kteři žijí v manželství (tab. 4).

- Subjektivní vývojový status slabě pozitivně souvisí $\mathrm{s}$ vnímanou připraveností $\mathrm{k}$ rodičovství $(\mathrm{r}=0,31$; $\mathrm{p}<0,001)$.

Tab. 4: Výsledky Tukeyova post-hoc testu

\begin{tabular}{|c|c|c|c|c|c|}
\hline \multirow[t]{2}{*}{ Typ partnerského soužití } & \multicolumn{5}{|c|}{$\begin{array}{l}\text { Tukeyův HSD test; proměn.: Připravenost na rodičovství } \\
\text { Označené rozdíly jsou významné na hladině } a<, 05\end{array}$} \\
\hline & $\{1\}(M=4,419)$ & $\{2\}(M=5,723)$ & $\{3\}(M=3,924)$ & $\{4\}(M=4,029)$ & $\{5\}(M=4,250)$ \\
\hline bydlíme s prítelem/kyní spolu \{1\} & & 0,001 & 0,008 & 0,206 & 0,997 \\
\hline manželství $\{2\}$ & & & 0,001 & 0,001 & 0,027 \\
\hline vídáme se přes týden (po-ne), ale nebydlíme spolu $\{3\}$ & & & & 0,983 & 0,960 \\
\hline vídáme se jen o víkendech (prázdninách, svátcích) \{4\} & & & & & 0,991 \\
\hline vztah na dálku (vídáme se méně než $1 \times$ za měsíc) $\{5\}$ & & & & & \\
\hline
\end{tabular}




\section{Diskuze}

Výzkumný projekt si kladl za cíl zjistit, zda existuje souvislost mezi typem vztahové vazby (jistý-nejistý) a připraveností $\mathrm{k}$ rodičovství u mladých dospělých (18-35 let) v České republice. Sekundárním cílem pak bylo ověření souvislosti dalších faktorů s připraveností k rodičovství - pohlaví, věku, aspektů partnerského vztahu (délka, spokojenost, typ soužití) a subjektivního vývojového statusu.

V souladu se stanovenými cíli práce bylo k jejich dosažení využito dotazníku vlastní konstrukce s otázkami na možné mediátory připravenosti $\mathrm{k}$ rodičovství doplněného škálou ECR-CZ. Zkrácenou 31položkovou českou verzi škály Experiences in Close Relationships (ECR-CZ) jsme pro náš výzkum zvolili pro její délku, psychometrickou přesnost a proto, že těžiště věkového rozložení výběrového souboru pro tvorbu norem bylo v období mladé dospělosti (Seitl et al., 2016). Důvodem volby škály ECR byl také fakt, že je jednou z nejrozšírenějších sebeposuzovacích škál a navíc respektuje dvoudimenzionální přístup a od roku 2012 existuje v adekvátním českém překladu originální verze (Lečbych \& Pospíšilíková, 2012). Pro formulaci klíčové závisle proměnné pripravenost $k$ rodičovství jsme vytvořili položku v první části dotazníku se sedmibodovou škálou Guttmanova typu, jež splňovala naše požadavky na vyjádření subjektivního pocitu připravenosti. Škála Guttmanova typu je typická tím, že souhlas s daným tvrzením současně vyjadřuje souhlas se všemi tvrzeními nižšího řádu (Dostál, 2015). Současně je tato volba i možným limitem v našem výzkumu, jelikož se nejedná o standardizovanou položku.

K primárnímu cíli se vztahovala $\mathrm{H} 1$, která byla po ověření statistickým T-testem pro dva nezávislé výběry přijata $(t=-3,187 ; p=0,001)$. Míra praktické významnosti je ale nízká, vyjádřená hodnotou Cohenova $\mathrm{d}=0,32$. Po přijetí $\mathrm{H} 1$ můžeme říci, že připravenost $\mathrm{k}$ rodičovství souvisí nejen s typem vztahové vazby, ale i že vnímaná připravenost je vyšší u lidí s jistým typem vztahové vazby než u těch, jejichž skóry odpovídají typu nejistému. Toto zjištění koresponduje např. s výsledky výzkumu Rholese a kol. (1997), jež se zaměřovali na touhu mít děti. Po provedení dílčí analýzy a rozdělení vztahové vazby do 4 kategorií jsme v našem výzkumu došli k dalším výsledkům, které jsou v souladu se studií Rholese a jeho týmu. I přes nerovnoměrné zastoupení našich respondentů v každé kategorii se ukázalo, že vyhýbaví respondenti vnímali sami sebe jako potenciální rodiče negativně a na dítě se ještě připraveni necítí, zatímco úzkostní respondenti navzdory nejistotě a pochybnosti o sobě samých tíhnou k tomu dítě mít a cítí se do jisté míry připravení (Rholes et al., 1997). K podobným závěrům došla ve svém výzkumu i Kramolišová (2017), která zkoumala citovou vazbu k rodičům a postoje k rodičovství, a z jejích výsledků vyplývá, že vyšší míra prožívané péče (odpovídající jistému typ vazby) predikuje pozitivní postoj k rodičovství a úmysl stát se rodičem $\mathrm{v}$ dřívějším věku. Na tomto místě ale považujeme za důležité zmínit, že hlavním nástrojem výzkumné studie Rholese a kol. (1997) ani Kramolišové (2017) nebylo ECR. Jednalo se v prvním případě o Adult Attachment Questionaire (AAQ) a v druhém o Parental Bonding Instrument (PBI). V tomto kontextu není možné přesné srovnání výsledků, nicméně v obecné rovině výkladu teorie vztahové vazby zde existuje zjevná paralela. Vzhledem k tomu, že studie zabývající se připraveností k rodičovství a vztahovou vazbou zjištovanou za pomocí ECR nebyla dosud realizována, jsou výsledky výše zmíněných studií nejbližšími, které nabízejí možné srovnání. Navíc, pokud odhlédneme z pole výzkumného do pole čistě teoretického, výsledný signifikantní výsledek v H1 je podpořen i teoretickým výkladem chování jistého typu (celkově se vyznačuje vyšší psychickou stabilitou a schopností regulovat své emoce) (Mikulincer \& Shaver, 2007), což na tomto místě interpretujeme jako schopnost se zodpovědně vyjádřit o subjektivním pocitu připravenosti k rodičovství.

K sekundárnímu cíli se vztahovaly zbývající hypotézy, prostřednictvím kterých se testovaly další možné mediátory připravenosti. Faktor pohlaví se neprokázal jako signifikantní - není tak rozdíl ve vnímané připravenosti mezi muži a ženami. Jako možný důvod zvažujeme níže uvedený limit předkládané studie, a to výrazně nerovnoměrné zastoupení mužů a žen ve vzorku. Další testovaná nezávisle proměnná, věk, prokázala slabý pozitivní vztah v souvislosti s vnímanou připraveností $\mathrm{k}$ rodičovství. V kontextu studované teorie a dostupných výzkumů ale považujeme věk za faktor, který sám o sobě není tolik významný jako subjektivní vývojový status - jak dospělý se jedinec v daném věku cítí. Na rozdíl od výzkumu Macka, Bejčka a Vaníčkové (2007) se většina mladých dospělých v našem vzorku neidentifikuje jako vynořující se dospělí („někde mezi“ se cítí pouhých $16 \%$ ). Musíme ale zohlednit fakt, že respondenti v jejich výzkumu byli ve věku 18-27 let, zatímco naši respondenti jsou z kategorie 18-35 let. Právě jedinci kolem 30. roku života mohou být v naší studii ti, kteří výsledky ovlivnili. Z našich výsledků dále vyplývá, že existuje slabý vztah subjektivního vývojového statusu k vnímané připravenosti k rodičovství $(\mathrm{H} 7)$. Zajímavým zjištěním jsou pak dílčí výsledky z testování H7, které neukázaly očekávanou tendenci - „čím dospělejší, tím připravenějšíc. Macek a kol. (2007) navíc souvislost mezi subjektivním vývojovým statusem a rolí rodiče ověřovali u respondentů, kteří již děti mají, což je situace odlišná od té námi prezentované. Můžeme se tak pouze domnívat a v souladu s teoretickým zjištěním interpretovat naše výsledky z dílčí analýzy pro H7 jako paralelu s charakteristikou mladé dospělosti. Ta je popisována jako období velmi dynamické, do kterého 
spadá rodičovství jako vývojový úkol, nicméně zde působí mnoho dalších proměnných (věk, status, existence partnerského vztahu, ...) (Thorová, 2015; Vágnerová, 2007).

Další testované faktory v souvislosti se sekundárním cílem předkládané práce se vztahovaly k partnerskému vztahu. $V$ dílčí analýze se potvrdil předpoklad, že jedinci, kteř́ jsou v partnerském vztahu, se cítí na rodičovství připravenější než ti, kteří jsou aktuálně nezadaní, přičemž toto zjištění je v souladu s mnoha dalšími studiemi ze zahraničí (např. Jaccard et al., 2003; Kamp Dush et al., 2014; Rholes et al., 1997) i na českém území (např. Divíšková, 2017; Fialová et al., 2000; Vaverová, 2018). Podrobněji jsme se potom u zadaných respondentů $(\mathrm{N}=443 ; 71 \%)$ zaměřili na proměnné délka vztahu, spokojenost ve vztahu a typ soužití. Délka vztahu koreluje s připraveností pouze slabě, nicméně vykazuje rostoucí tendenci, že s délkou vztahu roste pocit připravenosti. I ve výzkumu nacházíme oporu pro naše zjištění, jelikož vybraní výzkumníci uvádějí souvislost s délkou vztahu a pocitem jistoty a stability (Carter, Kraft, Hock-Long, \& Hatfield-Timajchy, 2013). Uvážíme-li fakt, že rodičovství je často považováno za velký životní mezník, významný vývojový úkol a roli, jež s sebou nese množství změn, pocit jistoty a stability zde má nezanedbatelnou roli. Na tomto místě pomýšlíme na paralelu s chováním jedinců s různými typy vztahové vazby v partnerských vztazích, konkrétně na chování z hlediska spokojenosti ve vztahu. Narážíme konkrétně na studii Davila a Bradburyho (2001), kteří výzkumně ověřili předpoklad, že jedinci s úzkostným typem vazby dlouhodobě setrvávají i ve vztazích, ve kterých nejsou spokojení. Takové chování reflektuje pochybnosti o sobě samém a přehnanou závislost na druhém, což je typickým projevem chování úzkostného typu. To nás přivádí na myšlenku nutnosti kritické interpretace pojmu stability vztahu jakožto paralely $\mathrm{k}$ délce vztahu a tím i spokojenosti, protože je vždy třeba uvážit množství dalších faktorů (jako např̀ již zmíněný typ citové vazby).

Když už jsme na tomto místě odbočili k citové vazbě, nabízí se další uvedení do souvislostí, kdy např. Molero se svým týmem (2016) ve své studii poukázali na pozitivní vztah mezi partnerskou spokojeností a jistým typem vztahové vazby - takoví jedinci se cítí ve vztahu spokojenější a jsou schopni se lépe adaptovat na změny (např. role rodiče). Vrátíme-li se zpět k výsledkům naší studie, i my jsme našli již výše zmíněnou souvislost vyšší vnímané připravenosti k rodičovství u respondentů s jistým typem vazby ve srovnání s typem nejistým. Při testování samotné proměnné spokojenost ve vztahu $\mathrm{v}$ souvislosti $\mathrm{s}$ připraveností $\mathrm{k}$ rodičovství byl $\mathrm{v}$ našem výzkumu prokázán pouze slabě pozitivní vztah. Zajímavým zjištěním byl velký rozptyl odpovědí týkajících se vnímané připravenosti u respondentů, kteří nebyli ve vztahu spokojeni (respondenti, kteř́ volili odpověd' 2 - „Velmi neštastný"). Skór ECR-CZ u všech odpovídal jistému typu vazby, proto $\mathrm{k}$ interpretaci nelze použít výše popsanou spojitost s úzkostným typem vazby a setrváváním ve vztahu, ve kterém jedinec není spokojen. Nabízí se tedy zamyšlení nad dalšími souvislostmi, např. věk, pokud bychom uvažovali hypotézu o tzv. „tikajících biologických hodinách“. Věkový průměr této skupiny respondentů je ale pouhých 23 let, což v kontextu současného vývoje společnosti nelze považovat za vyloženě „hraniční pro rodičovství. Průměrný věk uváděný jako vhodný pro rodičovskou roli je např. dle probandů ze studie Lampice a kol. (2006) 28 let u žen a 30 let u mužů. Na české půdě přišla např. Kramolišová (2017) s obdobnými čísly - ženy by chtěly dítě v průměru ve 27 letech, muži ve 28 letech - a s jejími výsledky se shoduje i Vaverová (2018), která uvádí průměrný věk pro početí prvního potomka 27 let.

$\mathrm{V}$ neposlední řadě byla $\mathrm{v}$ našem výzkumu ve spojitosti s partnerským vztahem prokázána souvislost mezi manželstvím jako typem soužití a vnímanou připraveností k rodičovství. Zde vstupují do hry opět další faktory, které se statusem manželství souvisejí, jako např́íklad socioekonomická jistota, která se dle Fialové (2000) pozitivně promítá do připravenosti na roli rodiče. Kromě zmíněné socioekonomické jistoty také uvažujeme o svazku manželském v kontextu závazku, tradice i sociální role. Goodmanová a Greavesová (2010) publikovaly rozsáhlou longitudinální studii, ve které srovnávaly kohabitaci a manželství. Z jejich poznatků vyplývá, že manželství jako instituce poskytuje partnerskému vztahu jistotu a vyznačuje se vyšší mírou závazku vůči partnerovi, což se promítá do stability celého vztahu. Rodičovství manželů jsou ve srovnání $s$ jedinci v nesezdaném soužití častěji plánovaná a partneři po narození potomka snáze překonávají krize a poskytují si podporu. Závěrem lze $\mathrm{k}$ diskutovaným faktorům pouze dodat, že námi zkoumané proměnné pravděpodobně interferují i mezi sebou navzájem a mohou významně subjektivní pocit připravenosti ovlivňovat pozitivně i negativně. Toto prolínání a působení námi zkoumaných faktorů by mohlo být námětem pro další výzkum.

Volně tak přecházíme $\mathrm{k}$ doporučením pro další zkoumání. Ta by se mohla ubírat např. směrem $\mathrm{k}$ longitudinální studii připravenosti $\mathrm{k}$ rodičovství před a po narození dítěte se zaměřením na faktory, které pocit připravenosti ovlivňují. Další potenciál vidíme v podrobnějším kvalitativním bádání o vnímané připravenosti ve skupinách respondentů dle typu vazby (jistý-nejistý) s následným porovnáním. Zajímavé by také mohlo být porovnání vnímané připravenosti u rodičů a „nerodičü“ nebo u sezdaných a nesezdaných párů za pomoci dvou ekvivalentních forem dotazníku. Pozornému čtenáři pravděpodobně neuniklo, že třetí 
část našeho dotazníku, složená z položek volně inspirovaných škálou GIDS, nebyla zmíněná nikde ve výsledcích. V procesu analýzy dat vyplynulo, že interpretace výsledků z právě zmíněných položek v třetí části našeho dotazníku je velmi náročná a nepřirozená v kontextu předkládané práce. Domníváme se, že je to zpưsobené pravděpodobně tím, že se bohužel nejedná o nástroj adekvátní našemu výzkumu, protože námi zkoumaná připravenost $\mathrm{k}$ rodičovství není postojem (či konceptem) ve smyslu, na který je škála GIDS primárně cílena. O toto zjištění opíráme další doporučení pro návazný výzkum, a to nalezení jiné škály nebo dotazníku, případně jeho vytvoření, jenž by mapoval připravenost $\mathrm{k}$ rodičovství v kontextu diskutovaných faktorů, nikoliv míru závazku k postoji $\mathrm{k}$ rodičovství.

Závěrem nemůžeme opomenout ani potenciální zdroje chyb a nepřesností, stejně jako limity výzkumu této práce. Prvním potenciálním limitem je zvolené kvantitativní dotazníkové šetření realizované online. Za možné riziko považujeme absenci přítomnosti administrátora dotazníku pro př́pad, že by některá z položek dotazníku nebyla srozumitelná. Toto riziko jsme se snažili minimalizovat realizací pilotního testování před samotným sběrem dat. Cílem realizované pilotní studie bylo především ověřit srozumitelnost položek a konzistentnost celého dotazníku. Na základně zpětné vazby byly některé otázky stylisticky upraveny do srozumitelnější formy a byla zvolena odlišná webová platforma, jež se jevila jako přehlednější a uživatelsky př́ijemnější. Toto opatření považujeme za dostatečné ošetření daného limitu. Kromě neporozumění položkám dotazníku si uvědomujeme jako limit online výzkumu i skutečnost, že z našeho výzkumu byli vyloučeni respondenti, kteří nemají přístup k internetu. Z údajů ČSÚ však vyplývá, že v roce 2017 se jednalo v součtu o pouhá $2 \%$ lidí ve věkových kategoriích 16-24 let a 25-34 let, kteří v České republice nepoužívají internet (Český statistický úřad, 2017b).

Dalším potenciálním zdrojem nepřesností může být samotný výběrový soubor. Výsledný vzorek nemá rovnoměrné zastoupení co do věku i pohlaví. Je zde patrná převaha respondentů ve věku 21-25 let (63\%) a výrazná nevyrovnanost skupin dle pohlaví (17\% mužů a $83 \%$ žen). Tento limit se promítá především do omezených možností zobecnění výsledků výzkumu.

Vzhledem k absenci zpracování tématu připravenosti k rodičovství v souvislosti s teorií vztahové vazby přináší předkládaná práce, i s vědomím výše uvedených limitů, nové informace na pole vědeckého výzkumu. Výsledky našeho výzkumu mohou být dále rozšířeny o podrobnější prozkoumání faktorů ovlivňujících připravenost k rodičovství či o srovnání typu vztahové vazby a připravenosti $\mathrm{k}$ rodičovství dle typu rodičovského statusu („rodiče“ vs. „nerodiče“). Na tomto místě také považujeme za důležité zmínit proměnnou, která v námi zkonstruovaném dotazníku chyběla a ze zjištěného předpokládáme, že na vnímanou připravenost $\mathrm{k}$ rodičovství vliv má - status jedince na pracovním trhu, viz např. výzkum Fialové a kol. (2000): faktory pozitivně korelujícími s připraveností k rodičovství byly (po věku) dokončené vzdělání, ekonomické a materiální zajištění (výdělečná činnost s dostatečným příjmem, samostatné bydlení) a existence stabilního partnerského vztahu (Fialová, Hamplová, Kučera, \& Vymětalová, 2000). Další potenciál pro rozvoj tématu toho příspěvku vidíme $\mathrm{v}$ zaměření na aspekty partnerského vztahu v kontextu teorie vztahové vazby a vnímanou připravenost $\mathrm{k}$ rodičovství.

\section{Závěry}

Výsledky nasvědčují, že existuje souvislost mezi typem vztahové vazby a vnímanou připraveností k rodičovství. Jedinci se skóry odpovídajícími jistému typu vztahové vazby sami sebe vnímají jako připravenější k rodičovství než jedinci se skóry náležícími nejistému typu vztahové vazby. Navzdory tomu, že výsledek byl statisticky významný, míra účinku byla malá. Naopak výsledky nesvědčí pro rozdíl ve vnímané připravenosti k rodičovství mezi muži a ženami.

Z dalších faktorů byla prokázána souvislost připravenosti $\mathrm{k}$ rodičovství s věkem respondentů i se subjektivním vývojovým statusem. Z dílčích výsledků jednotlivých aspektů partnerského vztahu vyplynulo, že s vnímanou připraveností k rodičovství souvisí délka vztahu, spokojenost ve vztahu i typ soužití.

\section{Poděkování}

Vydání této studie bylo možné za podpory Interní grantové agentury FF UPOL jako část projektu IGA FF_2018_019: Psychologický výzkum ve vybraných oblastech pedagogické a klinické psychologie III. Děkujeme všem respondentům, kteří se do výzkumu zapojili. V rámci této studie není předpokládán konflikt zájmů.

\section{Literatura}

Ainsworth, M. S., Bell, S. M., \& Stayton, D. S. (1971). Individual differences in Strange Situation behavior of one-year-olds. In The origins of human social relations (Schaffer, H. M., s. 17-57). London: Academic Press.

Arnett, J. J. (2000). Emerging Adulthood: A Theory of Development From the Late Teens Through the Twenties. American Psychologist, 55(5), 469-480.

Arnett, J. J. (2004). Emerging Adulthood: The Winding Road From the Late Teens Throught the Twenties. Oxford: University Press.

Bowlby, J. (1988). A Secure Base: Clinical applications of attachment theory. London: Routledge.

Bowlby, J. (2010). Vazba. Praha: Portál.

Brennan, K. A., Clark, C. L., \& Shaver, P. R. (1998). SElf-report measurement of adult attachment: An integrative overview. 
In Attachment theory and close relationships (Rholes W.S., s. 46-76). New York.

Brisch, K. (2011). Poruchy vztahové vazby: od teorie k terapii. Praha: Portál.

Carter, M., Kraft, J. M., Hock-Long, L., \& Hatfield-Timajchy, K. (2013). Relationship characteristics and feelings about pregnancy among black and puerto rican young adults. Perspectives on sexual and reproductive health, 45(3), 148-156. Česká republika. (b.r.). $\$ 30$ zákona č. 89/2012 Sb., občanský zákoník, ve znění pozdějších předpisů. Získáno $\mathrm{z}$ https:// www.zakonyprolidi.cz/cs/2012-89\#p30

Český statistický úřad. (2017a). Demografická příručka - 2016. Český statistický úrad. Získáno z https://www.czso.cz/csu/czso/ demograficka-prirucka-2016

Český statistický úřad. (2017b). Jednotlivci v ČR použivající internet - 2017. Český statistický úrad. Získáno z https:// www.czso.cz/documents/10180/46014700/06200417022. pdf/13995ffa-28a0-42a4-b538-c2f2dd8c9374?version=1.1

Davila, J., \& Bradbury, T. N. (2001). Attachment insecurity and the distinction between unhappy spouses who do and do not divorce. Journal of Family Psychology, 15(3), 371-393.

Divíšková, P. (2017). Láska a partnerství v mladé dospělosti podle Sternbergovy triangulární škály lásky. Nepublikovaná diplomová práce. FF Univerzity Palackého v Olomouci.

Dostál, D. (2015). Psychometrie. Získáno z dostal.vyzkumpsychologie.cz/soubory/psychometrie.pptx

Erikson, E. (1968). Identity, youth, and crisis. New York: Norton.

Fialová, L., Hamplová, D., Kučera, M., \& Vymětalová, S. (2000). Představy mladých lidí o manželství a rodičovství. Praha: Sociologické nakladatelství.

Fonagy, P., \& Target, M. (2005). Psychoanalytické teorie: perspektivy z pohledu vývojové psychopatologie. Praha: Portál.

Goldberg, S. (2000). Attachment and Development. New York: Oxford University Press.

Goodman, A., \& Greaves, E. (2010). Cohabitation, marriage and child outcomes. Institute for Fiscal Studies. Získáno z https://www.ifs.org.uk/comms/comm114.pdf

Hartl, P., Císařová, H., \& Nepraš, K. (2010). Velký psychologický slovník. Praha: Portál.

Hašto, J. (2005). Vztahová vazba: ku kořeňom lásky a úzkosti. Trenčín: Vydavatelstvo F.

Hazan, C., \& Shaver, P. R. (1987). Romantic love conceptualized as an attachment process. Journal of Personality and Social Psychology, 52(3), 511-524. https://doi.org/ doi:10.1037/0022-3514.52.3.511

Hazan, C., \& Shaver, P. R. (1994). Attachment as an organizational framework for research on close relationships. Psychological Inquiry, 5, 1-22.

Howe, D. (2011). Attachment Across the Lifecourse. London: Palgrave Macmillan.

Hurlock, E. B. (1980). Developmental Psychology: A Life-Span Approach (5.). New York: McGraw-Hill Companies.

Jaccard, J., Dodge, T., \& Dittus, P. (2003). Original article: Do adolescents want to avoid pregnancy? Attitudes toward pregnancy as predictors of pregnancy. Journal Of Adolescent Health, 33(2), 3379-3383. https://doi.org/10.1016/

S1054-139X(03)00134-4
Kamp Dush, C. D., Rhoades, G. K., Sandberg-Thoma, S. F., \& Schoppe-Sullivan, S. J. (2014). Commitment Across the Transition to Parenthood Among Married and Cohabiting Couples. Couple and Family Psychology: Research and Practice, 3(2), 126-136.

Kramolišová, I. (2017). Souvislost mezi citovou vazbou $k$ rodičưm a postoji $k$ rodičovství v období vynořující se dospělosti. Nepublikovaná bakalářská práce. FSS MU v Brně.

Kubička, L., \& Matějček, Z. (2003). Rodičovské Chování v pohledu dospívajících a sebepercepce v dospělosti: Prospektivní studie. Československá psychologie: Časopis pro psychologickou teorii a praxi, 47(6), 481-490.

Lampic, C., Svanberg, A. S., Karlström, P., \& Tydén, T. (2006). Fertility awareness, intentions concerning childbearing, and attitudes towards parenthood among female and male academics. Human Reproduction, 21(2), 558-564. https:// doi.org/10.1093/humrep/dei367

Langmeier, J., \& Krejčířová, D. (2006). Vývojová psychologie. Praha: Grada.

Lečbych, M., \& Pospíšilíková, K. (2012). Česká verze škály Experiences in Close Relationships (ECR): Pilotní studie posouzení vztahové vazby v dospělosti. E-psychologie, 6(3), $1-11$.

Levinson, D. J. (1996). The seasons of a woman's life. New York: Alfred Knopf.

Levinson, D. J., Darrow, C. N., Klein, E. B., \& Levinson, M. (1978). Season of a Man's Life. New York: Random House.

Macek, P., Bejček, J., \& Vaníčková, J. (2007). Contemporary Czech Emerging Adults. Journal of Adolescent Research, 22(5), 444-475.

Mikulincer, M., \& Shaver, P. R. (2007). Attachment in adulthood: Structure, dynamics and change. New York: Guildford Press.

Molero, F., Shaver, P. R., Fernández, I., Alonso-Arbiol, I., \& Recio, P. (2016). Longterm partners' relationship satisfaction and their perceptions of each other's attachment insecurities. Personal Relationships, 23(1), 159-171.

Obegi, J. H., \& Berant, E. (2009). Attachment Theory and Research in Clinical Work with Adults. New York: Guildford Press.

O'Laughlin, E. M., \& Anderson, V. N. (2001). Perceptions of Parenthood Among Young Adults: Implications for Career and Family Planning, 29(2), 95-108. https:// doi.org/10.1080/01926180125728

Plháková, A. (2007). Učebnice obecné psychologie. Praha: Academia.

Rholes, W. S., Simpson, J. A., Blakely, B. S., Lanigan, L., \& Allen, E. A. (1997). Adult Attachment Styles, the Desire to Have Children, and Working Models of Parenthood. Joumal of Personality, 65(2).

Říčan, P. (2004). Cesta životem. Praha: Portál.

Seitl, M., Charvát, M., \& Lečbych, M. (2016). Psychometrické charakteristiky české verze škály Experiences in Close Relationships (ECR). Československá psychologie, 60(4), 351-371.

Spiteri, G., Xuereb, R. B., Carrick-Sen, D., Kaner, E., \& Martin, C. R. (2014). Preparation for parenthood: a concept analysis. Journal of Reproductive and Infant Psychology, 32(2), 148-162. https://doi.org/10.1080/02646838.2013.869578 
Šolcová, I. (2009). Vývej resilience v dětství a dospělosti. Praha: Grada.

Švancara, J. (1981). Kompendium vývojové psychologie. Praha: SPN.

Thorová, K. (2015). Vývojová psychologie: Promèny lidské psychiky od početí po smrt. Praha: Portál.

Vágnerová, M. (2007). Vývojová psychologie II. Praha: Karolinum.

Vaverová, M. (2018). Fenomén odkládání mateřství v souvislosti s vývojovou fází mladší dospělosti. Nepublikovaná bakalářská práce. Ostrava: OSU.

\section{Informace 0 autorech:}

Lucie UCHYTILOVÁ*

Katedra psychologie FF UP Olomouc, Vodární 6, 77900 Olomouc, Česká republika,

e-mail: Lu.Uchytilova@seznam.cz

Provedla rešerši odborné literatury, vytvořila design studie, realizovala sběr, provedla analýzu dat.

\section{Lucie VIKTOROVÁ}

Katedra psychologie FF UP Olomouc, Vodární 6, 77900 Olomouc, Česká republika,

e-mail: lucie.viktorova@upol.cz

Vedla odborné konzultace v otázkách teoretických i praktických (design studie, analýza a interpretace dat). 